\title{
SPECTRUL MUTAȚIILOR INDUSE LA INUL DE CULTURĂ PRIN UTILIZAREA RAZELOR GAMA
}

\author{
Cuţitaru Doina \\ Institutul de Genetică, Fiziologie şi Protecție a Plantelor, Chişinău, Republica Moldova \\ e-mail:doina.cutitaru@gmail.com
}

Inul de cultură (Linum usitatissimum L.) reprezintă un important obiect de studiu grație caracteristicilor sale unicale. Din punct de vedere al direcției de utilizare această cultură este divizată, de regulă, în două grupuri distincte - inul pentru ulei şi inul pentru fibre. În scopul satisfacerii necesităţilor de produse extrase din in cercetătorii apelează la diverse procedee de ameliorare, astfel au fost create noi forme rezistente la factorii stresogeni ai mediului. Una din metodele utilizate ține de iradierea seminţelor cu razele $\gamma$, fapt ce conduce la sporirea variabilităţii genetice şi obţinerea unor noi soiuri economic valoroase. În studiul nostru s-a utilizat materialul semincer a trei genotipuri de in, care diferă după un complex de caractere morfobiologice şi agronomice. Pentru soiurile Dichl 8 şi Kaufmann este caracteristică apartenența la tipul de in pentru ulei, culoarea albastră a corolei. Soiul Belinka, însă, are corola de culoare albă şi aparţine tipului de in pentru fibre, a cărui importanţă este orientată spre producţia de tulpini. Seminţele de in au fost tratate cu diferite doze de iradiere (400$700 \mathrm{~Gy}$ ), folosindu-se ca sursă izotopul ${ }^{60} \mathrm{Co}$. S-a întrebuinţat un număr stabil de seminţe, câte 500 pentru fiecare probă. În calitate de martor au servit seminţele neprelucrate. Experienţele au fost montate în teren deschis. Incepând cu generaţia $\mathrm{M}_{1} \mathrm{~s}$-a observat un grad sporit de eliminare a plantelor. La etapa inițială de dezvoltare procentul de răsărire a variat semnificativ, constituind la s. Dichl 8 29,8\% (doza 400 Gy), 31,0\% (500 Gy), 45,0\% (600 Gy) și 27,4\% (700 Gy), Pentru soiul Belinka iradiat cu dozele menționate mai sus răsărirea a fost, corespunzător, la nivelul de $21,8 \%$, $16,6 \%, 14,4 \%$ și 16,2\%. Soiul Kaufmann a înregistrat următoarele date: 30,2\% (400 Gy), 28,2\% (500 Gy), 45,2\% (600 Gy), 35,4\% (700 Gy). La această etapă plantele s-au dovedit a fi mai rezistente faţă de s. Dichl 8 cu $6,1 \%$ şi cu $70,0 \%$ față s. Belinka. Totuşi, pe parcursul perioadei de vegetaţie s-a produs o eliminare substanţială a materialului iradiat. Sub influenţa iradierii şi a factorilor limitativi ai mediului soiul Belinka s-a dovedit a fi cel mai puţin rezistent, plantele iradiate fiind eliminate în totalitate. Procentajul de plante rămase fusese foarte mic atât pentru s. Dichl 8 (cuprins între 0,2$1,6 \%$ ), cât şi pentru s. Kaufmann 0,6-3,8\%. Inălţimea plantelor soiului Dichl 8 a înregistrat o valoare de 59,0 cm (500 Gy), fiind la acelaşi nivel cu martorul (58,4 cm). Ultimul, însă, a depăşit în înălţime cu 19,4 cm plantele obținute din iradierea cu doza 400 Gy şi cu 13,5 cm pe cele cu doza de 600 Gy. După acest parametru soiul martor Kaufmann a înregistrat valori de 43,2 cm, fiind depăşit de plantele din varianta $500 \mathrm{~Gy}$ cu $5,5 \mathrm{~cm}$ şi cu $1,73 \mathrm{~cm}$ (varianta $600 \mathrm{~Gy}$ ). Plantele obţinute în urma tratării cu doza de $400 \mathrm{~Gy}$ au demonstrat valori similare cu martorul $(42,8 \mathrm{~cm})$, iar cele mai joase exemplare sau semnalat în varianta 700 Gy $(36,8 \mathrm{~cm})$. După parametrul numărul de ramificaţii martorii Dichl 8 $(10,8)$ şi Kaufmann $(12,2)$ nu au fost depăşiţi de nici o formă iradiată. După numărul de flori şi fructe per plantă, însă, s. Dichl 8 sub influenţa dozei de 500 Gy a înregistrat cele mai mari valori (152,5 flori), respectiv 73,5 fructe, iar martorul - 105,4 şi 77,0. În același timp, la Kaufmann martorul a avut cele mai mici valori (de 78,8 şi 48,8) comparativ cu formele iradiate, numărul maxim de flori şi capsule au fost semnalate la plantele obținute din aplicarea dozei de 700 Gy - 186,9 flori şi 76,6 capsule. După caracterul numărul de semințe valoarea maximă s-a evidențiat la forma Dichl 8 (doza 400 Gy) - 7,9 comparativ cu martorul $(6,6)$, iar valorile obținute la genotipul Kaufmann $(6,8)$ în varianta 600 Gy nu diferă semnificativ de cele ale martorului. Screening-ul formelor mutante se va efectua și în generaţiile $\mathrm{M}_{2-3}$.

Utilizarea factorilor mutageni fizici permite de a obţine forme noi de in cu caractere agronomice valoroase utile pentru includerea în schemele de ameliorare genetică a culturii. 